\title{
Relation between fluid end-members and noble gases in South African diamonds
}

\author{
Suzette Timmerman ${ }^{1}$, Masahiko Honda ${ }^{1}$, David Phillips ${ }^{2}$, A. Lynton Jaques ${ }^{1}$, Jeff W. \\ Harris $^{3}$ \\ ${ }^{1}$ Australian National University, Canberra, Australia, suzette.timmerman@anu.edu.au, \\ masahiko.honda@anu.edu.au,lynton.jaques@anu.edu.au \\ ${ }^{2}$ University of Melbourne, Parkville, VIC, Australia, dphillip@unimelb.edu.au \\ ${ }^{3}$ University of Glasgow, Glasgow, United Kingdom, jeff.harris@glasgow.ac.uk
}

\section{Introduction}

Fibrous diamond growth zones can contain abundant high density fluid inclusions (HDFs) and these provide the most direct information on the source and composition of diamond-forming fluids. Four different fluid end-members have been defined; silicic, low-Mg carbonatitic, high-Mg carbonatitic, and saline (Weiss et al. 2015 and references therein). Continuous arrays exist between the silicic and low-Mg carbonatitic end-member and between the saline and high-Mg carbonatitic end-member. Different processes have been proposed to explain the two major element compositional arrays, but the origin of and relation between the various fluid end-members is still debated. In this study we provide new constraints on the evolution and origin of these diamond-forming fluids by combining noble gas systematics with $\delta^{13} \mathrm{C}, \mathrm{N}$ concentrations, and fluid inclusion compositions. The rationale is that as noble gases are primarily concentrated in the HDFs in diamonds (Burgess et al. 2009; Johnson et al. 2000), there could potentially be a relationship between the noble gas and fluid inclusion compositions. To this end, we have studied 24 growth zones from 14 diamonds from the Finsch $(n=4)$, De Beers Pool $(n=7)$, and Koffiefontein $(n=3)$ mines, located along a west to east transect on the Kimberley Block in South Africa. Noble gases from fluid inclusions were extracted by crushing.

\section{Results}

Twelve of the studied diamonds are opaque and have fibrous growth zones, whilst the other two (from the Finsch mine) have a milky appearance in normal reflected light with few fluid inclusions. The carbon isotope compositions for the fibrous opaque diamonds range from -2.8 to $-8.6 \%$, whereas the milky diamonds have $\delta^{13} \mathrm{C}$ values up to $-1.6 \%$. The majority of the fibrous diamonds are $100 \%$ IaA and have nitrogen concentrations ranging from 310 to $800 \mathrm{ppm}$. The milky diamonds from Finsch contain 30-40 ppm (diamond 03) and 800-1000 ppm (diamond 04), with diamond 04 having a strong hydrogen peak and clear aggregation to $\mathrm{IaB}$ (up to $40 \%$ ). There is no relation between $\delta^{13} \mathrm{C}-\mathrm{N}$ and the noble gas isotopic composition, although in general, higher noble gas concentrations are found in the fibrous diamonds with higher nitrogen concentrations. The majority of the studied diamonds $(n=11)$ fall along the high-Mg carbonatitic to saline compositional array, whereas three diamonds fall on the silicic to low-Mg carbonatitic compositional array. ${ }^{4} \mathrm{He}$ concentrations range from 0.3-65.1 x10 $0^{-6}$ ccSTP/g, with saline diamonds from De Beers Pool having higher concentrations (3.4-65.1 $\times 10^{-6}$ ) than Finsch $\left(0.4-4.1 \times 10^{-6}\right)$ and Koffiefontein $\left(0.3-2.5 \times 10^{-6}\right.$; see Figure 1a). Similarly for ${ }^{40} \mathrm{Ar}$, the concentrations of De Beers Pool samples $\left(1.3-78.2 \times 10^{-7}\right)$ are in general higher than those of the Koffiefontein samples $\left(0.3-4.1 \times 10^{-7}\right) .{ }^{40} \mathrm{Ar} * /{ }^{4} \mathrm{He}$ ratios are lower for diamonds near the saline endmember $(<0.12)$ than for silicic diamonds ( $\geq 0.6$; Fig. 1b; 1.1-4.4 for Jwaneng diamonds; Burgess et al. 1998). The silicic-carbonatitic diamonds have low ${ }^{40} \mathrm{Ar} /{ }^{36} \mathrm{Ar}$ ratios of 390-1940, whereas saline diamonds have ${ }^{40} \mathrm{Ar} /{ }^{36} \mathrm{Ar}$ ratios up to 30,200 (Fig. 1c). ${ }^{22} \mathrm{Ne},{ }^{84} \mathrm{Kr}$ and ${ }^{132} \mathrm{Xe}$ yielded concentrations of $0.9-16.0 \times 10^{-11}, 0.4-28.2 \times 10^{-11}$ and $0.4-111 \times 10^{-12} \mathrm{cc} / \mathrm{g}$ respectively. $\mathrm{R} / \mathrm{Ra}$ values in this study range from 1.1 to 6.7 and the majority is similar to values in Panda diamonds (R/Ra: 3.0-6.4) studied via step-heating by Burgess et al. (2009): these show generally higher R/Ra and ${ }^{4} \mathrm{He}$ concentrations for saline diamonds (Fig. 1d). 

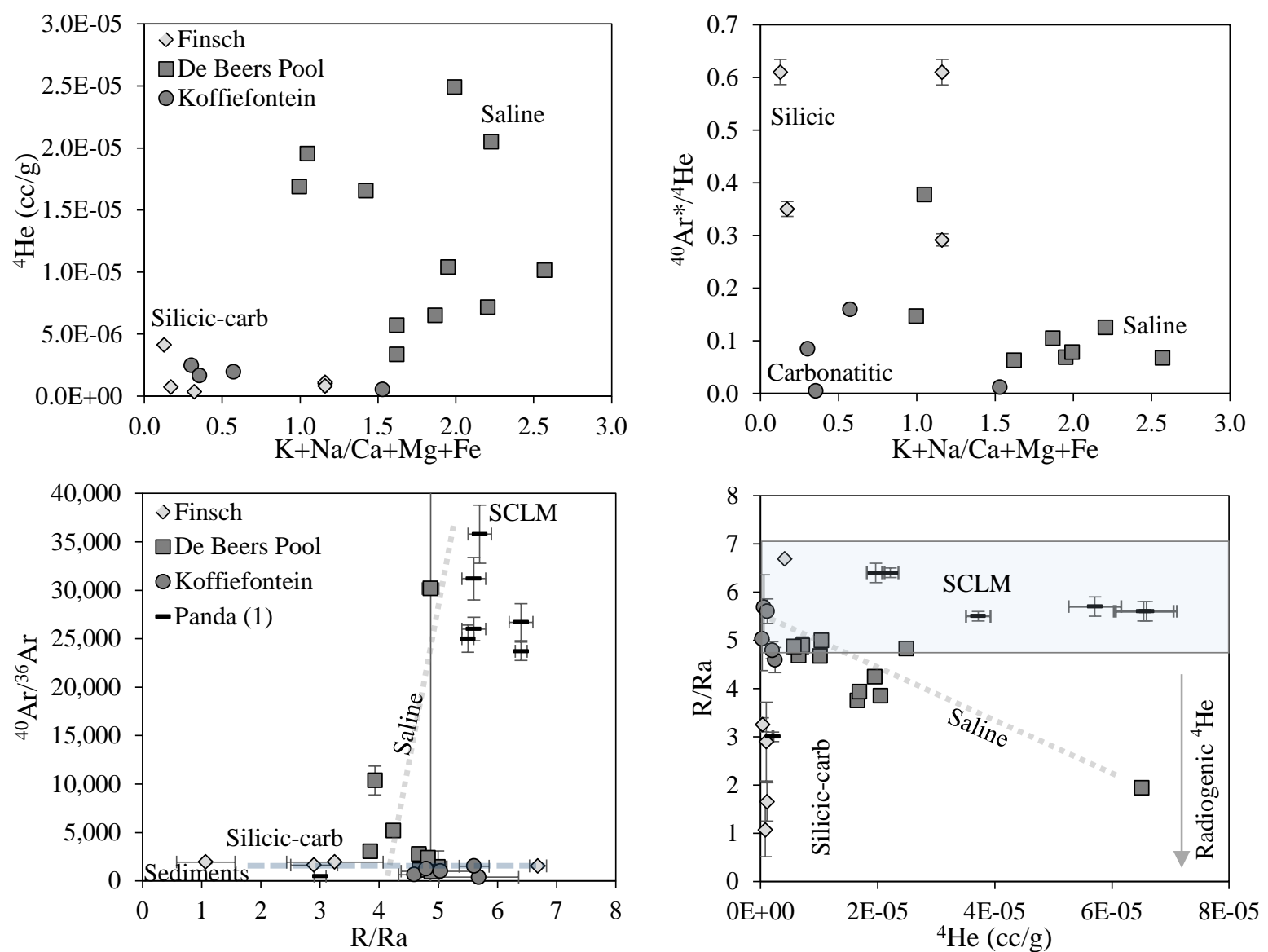

Figure 1: Relationship between the fluid composition and the noble gas compositions and concentrations. The salinity of the fluid composition is expressed as potassium plus sodium relative to calcium plus magnesium plus iron. A) ${ }^{4} \mathrm{He}$ concentrations versus salinity showing saline diamonds from De Beers Pool have higher helium concentrations. B) ${ }^{40} \mathrm{Ar} * /{ }^{4} \mathrm{He}$ versus the salinity of the diamonds. C) ${ }^{40} \mathrm{Ar} /{ }^{36} \mathrm{Ar}$ versus $\mathrm{R} / \mathrm{Ra}\left({ }^{3} \mathrm{He} /{ }^{4} \mathrm{He}_{\text {sample }} /\right.$ ${ }^{3} \mathrm{He} /{ }^{4} \mathrm{He}_{\text {air }}$ ) show some saline diamonds have sub-continental lithospheric mantle (SCLM) compositions. (1) Panda diamonds are from Burgess et al. (2009). The dashed line shows the range in saline diamonds. D) R/Ra versus ${ }^{4} \mathrm{He}$ concentration showing saline diamonds have higher concentrations but a more limited $\mathrm{R} / \mathrm{Ra}$ range, similar to the SCLM (R/Ra of 5.9 +/- 1.2; Day et al., 2005).

\section{Discussion}

Different sources and processes have been suggested to explain the two arrays and evolution of the diamond-forming fluid end-members. As the SCLM is not a closed system, possible sources include accreted mantle from convergent margins, subducted oceanic lithosphere plus sediments, asthenospheric mantle by underplating, and $\mathrm{H}_{2} \mathrm{O}-\mathrm{CO}_{2}$ fluids (e.g. kimberlites). The low ${ }^{40} \mathrm{Ar} /{ }^{36} \mathrm{Ar}$ and $\mathrm{R} / \mathrm{Ra}$ observed in the low-Mg carbonatitic HDF-bearing diamonds are very similar to the ratios of the atmosphere (296 and 1 respectively), sea-water (296; 1), oceanic crust (516; 0.04) and its sediments (374; n/a; Allègre et al. 1987). The observed low ${ }^{40} \mathrm{Ar}^{*} /{ }^{4} \mathrm{He}$ ratios can be explained by the loss of $\mathrm{K}$ relative to $\mathrm{U}$, Th during dehydration of the subducting slab. The noble gas characteristics of the carbonatitic HDFs are, however, also comparable to carbonatitic and kimberlitic magmas $\left({ }^{3} \mathrm{He} /{ }^{4} \mathrm{He}\right.$ ratios of $1 \times 10^{-8}$ to $1.06 \times 10^{-5}$ and ${ }^{40} \mathrm{Ar} /{ }^{36} \mathrm{Ar}$ ratios of 302 to 5000 ; Sasada et al. 1997 and references therein) and is supported by a limited range in halogen ratios (Burgess et al. 2009). Silicic HDFbearing diamonds have been related to eclogitic rocks (Weiss et al. 2015 and references therein) and this also appears consistent with their noble gas characteristics. The variable high ${ }^{40} \mathrm{Ar}^{*} /{ }^{4} \mathrm{He}$ ratios (this study; Jwaneng diamonds from Burgess et al. 1998) and variable R/Ra are likely related to the variation in $\mathrm{U} / \mathrm{He}$ and $\mathrm{K} / \mathrm{U}$ ratios in eclogites. The saline HDF-bearing diamonds in this study show some correlation between $\mathrm{R} / \mathrm{Ra}$ and ${ }^{4} \mathrm{He}$ concentration (Fig. 1d), suggesting a dependancy on radiogenic ${ }^{4} \mathrm{He}$ ingrowth over time. The ${ }^{40} \mathrm{Ar} /{ }^{36} \mathrm{Ar}$ ratios reach 35800 (this study; Burgess et al. 2009). The He and Ar isotope systematics of the saline diamonds are similar to the SCLM (4.7-7.1 R/Ra; 
Day et al. 2005). The R/Ra could also be explained by a HIMU source (4.2-6.7 R/Ra; Barfod et al. 1999) and is supported by relatively high $\mathrm{Cl}$ contents and $\mathrm{Cl} / \mathrm{K}$ (Stroncik and Haase 2004) in samples from HIMU sources, and a correlation of ${ }^{40} \mathrm{Ar} /{ }^{36} \mathrm{Ar}$ with $\mathrm{Cl} /{ }^{36} \mathrm{Ar}$ ratios (Johnson et al. 2000) in diamonds. The relatively low ${ }^{40} \mathrm{Ar}{ }^{36} \mathrm{Ar}$ ratios of HIMU sources $(<16300$; Barfod et al. 1999) are similar to the ${ }^{40} \mathrm{Ar} /{ }^{36} \mathrm{Ar}$ ratios of most saline diamonds in this study. The high ${ }^{40} \mathrm{Ar} /{ }^{36} \mathrm{Ar}$ of Panda saline diamonds (Burgess et al. 2009) suggests that saline fluids are influenced by the SCLM and possibly originate from a mix of a HIMU and SCLM source.

Different processes have been proposed to explain the continuous arrays between fluid end-members. The difference in ${ }^{40} \mathrm{Ar} /{ }^{36} \mathrm{Ar},{ }^{40} \mathrm{Ar} /{ }^{4} \mathrm{He}$ ratios, and $\mathrm{R} / \mathrm{Ra}$ values between saline and silicic HDFs may be explained with an immiscibility process by fractionation of $\mathrm{K}$ from U-Th (K more into saline fluid) and fractionation of light from heavy noble gases, but similar trace element patterns (Weiss et al. 2015 and references therein) suggest there is no significantly large $\mathrm{U}-\mathrm{Th} / \mathrm{K}$ fractionation. Fractional crystallisation of minerals such as carbonates has been proposed to explain the changes in major element composition. Changing isotopic compositions by crystallisation of minerals, however, seems unlikely on a short timescale. The simplest process to explain the correlations is by mixing the various end-member fluids from different sources. The volatility of noble gases will assist rapid mixing. Another possible process is metasomatic interactions with the wall rock in the SCLM. Carbonatitic fluids with low gas concentrations change composition readily when small volumes percolate through the mantle (eclogitic or peridotitic lithologies).

In summary, the combined fluid-noble gas results from this study provide important new insights into the origin of diamond-forming fluids. The noble gas characteristics of low-Mg carbonatitic HDFs are similar to the various components in a subducting slab and carbonatites/kimberlites. Saline fluids have noble gas compositions which most closely resemble a peridotitic host lithology in the SCLM or a mix of HIMU and SCLM. The noble gases of silicic fluids appear similar to eclogitic lithologies. From a noble gas perspective, the two compositional arrays between silicic and low-Mg carbonatitic and between saline and high-Mg carbonatitic fluids are best explained by mixing between the different sources or by a parental carbonatitic fluid interacting with the SCLM (eclogitic or peridotitic lithology).

\section{References}

Allègre CJ, Staudacher T, Sarda P (1987) Rare gas systematics: formation of the atmosphere, evolution and structure of the Earth's mantle. Earth and Planetary Science Letters 81(2-3):127-150

Barfod DN, Ballentine CJ, Halliday AN, Fitton JG (1999) Noble gases in the Cameroon line and the $\mathrm{He}, \mathrm{Ne}$, and Ar isotopic compositions of high $\mu$ (HIMU) mantle. Journal of Geophysical Research: Solid Earth 104(B12):29509-29527

Burgess R, Johnson LH, Mattey DP, Harris JW, Turner G (1998) He, Ar and C isotopes in coated and polycrystalline diamonds. Chemical Geology 146(3):205-217

Burgess R, Cartigny P, Harrison D, Hobson EL, Harris JW, (2009) Volatile composition of microinclusions in diamonds from the Panda kimberlite, Canada: implications for chemical and isotopic heterogeneity in the mantle. Geochimica et Cosmochimica Acta 73(6):1779-1794

Day JM, Hilton DR, Pearson DG, Macpherson CG, Kjarsgaard BA, Janney PE (2005) Absence of a high time-integrated ${ }^{3} \mathrm{He} /(\mathrm{U}+\mathrm{Th})$ source in the mantle beneath continents. Geology 33(9):733-736

Johnson LH, Burgess R, Turner G, Milledge HJ, Harris JW (2000) Noble gas and halogen geochemistry of mantle fluids: comparison of African and Canadian diamonds. Geochimica et Cosmochimica Acta 64(4):717-732

Sasada T, Hiyagon H, Bell K, Ebihara M (1997) Mantle-derived noble gases in carbonatites. Geochimica et cosmochimica acta 61(19):4219-4228.

Stroncik NA, Haase KM (2004) Chlorine in oceanic intraplate basalts: Constraints on mantle sources and recycling processes. Geology 32(11):945-948

Weiss Y, McNeill J, Pearson DG, Nowell GM, Ottley CJ (2015) Highly saline fluids from a subducting slab as the source for fluid-rich diamonds. Nature 524(7565):339-342 